\title{
GCU
}

Glasgow Caledonian

University

University for the Common Good

\section{Review of energy storage systems in electric grid and their potential in distribution networks}

Alhadi Al-Hamali, Abdul-Wahab; Farrag, Mohamed Emad; Bevan, Geraint; Hepburn, Donald M.

Published in:

18th International Middle East Power Systems Conference (MEPCON), 2016

DOI:

10.1109/MEPCON.2016.7836945

Publication date:

2017

Document Version

Author accepted manuscript

Link to publication in ResearchOnline

Citation for published version (Harvard):

Alhadi Al-Hamali, A-W, Farrag, ME, Bevan, G \& Hepburn, DM 2017, Review of energy storage systems in electric grid and their potential in distribution networks. in $\mathrm{OH}$ Abdalla (ed.), 18th International Middle East Power Systems Conference (MEPCON), 2016 ., 7836945, IEEE, 18th International Middle East Power Systems Conference (MEPCON), Cairo, Egypt, 27/12/16. https://doi.org/10.1109/MEPCON.2016.7836945

\section{General rights}

Copyright and moral rights for the publications made accessible in the public portal are retained by the authors and/or other copyright owners and it is a condition of accessing publications that users recognise and abide by the legal requirements associated with these rights.

Take down policy

If you believe that this document breaches copyright please view our takedown policy at https://edshare.gcu.ac.uk/id/eprint/5179 for details

of how to contact us. 


\section{Review of Energy Storage Systems in Electric Grid and their potential in Distribution Networks}

\author{
Abdulwahab Alhamali \\ Abdul.AlHamali@gcu.ac.uk
}

\author{
Mohamed Emad Farrag
}

Mohamed.Farrag@gcu.ac.uk
Geraint Bevan

Geraint.Bevan@gcu.ac.uk
Donald M Hepburn

D.M.Hepburn@gcu.ac.uk

Glasgow Caledonian University, Glasgow, UK

\begin{abstract}
Concerns over changes to the global environment and the growing need for energy have increased the penetration of renewable energy ( $R E)$ generation into low voltage distribution networks. The introduction of Energy Storage Systems (ESS) into distribution networks has been proposed to improve the reliability and performance of power systems. Energy storage systems will also be important in helping to regulate the supply from intermittent $R E$ sources that feed into variable load demand.

The focus of this paper is to provide an overview of the state of the art of ESS, concentrating on the distinct characteristics and applications of the different types. The analysis includes comparison and evaluation of different storage preferences with regard to integration of these technologies with an electric grid at the distribution network level that may lead to benefits such as distribution upgrade deferral and improvements in power quality and reliability.
\end{abstract}

Index Terms-- Energy storage systems, distribution networks.

\section{INTRODUCTION}

Because of the increased concerns regarding the environmental influences of the electricity sector, there has been growing interest in RE resources [1], such as wind turbines, photovoltaic systems, hydropower turbines, gas micro-turbines, fuel cells, hybrid power systems, biomass power plants and combined heat and power (CHP) microturbines, are used in power generation systems [9]. ESS allow capture and storage of RE for later use, instead of losing excess electricity for which there is no demand. In addition they are used to smooth the output from intermittent and unpredictable generators and to reduce exchange of power across the network [3]. In addition to the benefits listed above, ESS improves flexibility in supply of energy, by hiding the gap between supply and demand [4]. Therefore, ESS can enhance the efficiency of power systems; improve grid stability and reliability as well as contributing to continuity of supply and energy security [7]. Applications of ESS include vehicles and stationary energy resources, which may include distribution and transmission networks, renewable and distributed energy resources, and equipment belonging to local industrial and commercial customers [8].

\section{APPLiCATIONS OF ENERGY STORAGE SySTEMS}

Traditional electricity systems comprise several distinct links in the chain of provision: fuel production, power generation, transmission, distribution and end-user services. ESS can be considered as a sixth link, with a supporting role to play from generation to the end-user [8] - [12]:

$>$ fuel production: energy price arbitrage and forecast hedging;

$>$ power generation: time-shifting, voltage support spinning, black start, non-spinning, supplemental reserves, grid voltage and frequency regulation, suppression of fluctuations and load following;

$>$ transmission: curtailment, congestion relief and postponement of infrastructure upgrades;

> distribution infrastructure services: voltage support and postponement of infrastructure upgrades ;

$>$ end-user services: power reliability and quality;

\section{KEY CHARACTERISTICS OF ENERGY STORAGE TECHNOLOGY}

There are many criteria that are considered when choosing an ESS for a particular application [1], [15], some of which are described in this section:

A. storage power rating: to indicate the power $(\mathrm{kW})$ and energy $(\mathrm{kWh})$, i.e. the maximum rate of charging or discharging at any given instant and the the capacity of stored energy;

B. round-trip efficiency: to represent the quantity of stored electricity which can ultimately be extracted;

C. lifetime (cycle and calendar): to account for degradation during each cycle of charging and discharging, such degradation being exhibited by most types of ESS and particularly electrochemical batteries, depending on many 
variables such as storage technology type, and operating conditions; and

D. other characteristics: including response time, ease of maintenance, cost, memory effects, self-discharge, environmental impact, reliability and level of maturity [8], [9],[15],[24], [27].

\section{TYPES OF ENERGY STORAGE SYSTEMS}

Overall, there are four classifications of ESS: mechanical, electrical, thermal and chemical [2],[5],[19].

\section{A. Mechanical Energy Storage}

Compressed air and pumped hydro technologies store potential energy, while flywheels store kinetic energy.

\section{1) Compressed air energy storage (CAES)}

Compressed air systems can store huge quantities of energy; more than $100 \mathrm{MW}$ for utilities. Huntorf, the largest one in Germany with a discharge power of $321 \mathrm{MW}$, has a round-trip efficiency of roughly $41 \%$ [10]. Traditionally, to increase efficiency, compressed air is used with natural gas [2]. However, the low round-trip efficiency and geographic limitation of locations are considered to be disadvantages of this technology [10]. In addition to these large-scale applications, small-scale systems are availabl,e using distributed high-pressure reservoirs or pipes [4]. Such systems can have overall efficiencies of 50\%. This type has been planned in the US to provide temporary support for the network (small scale compressed air energy storage: SSCAES).

\section{2) Pumped-hydro storage (PHS)}

Hydro-electric schemes are the most well-known type of ESS, with a global installed capacity around $130 \mathrm{GW}$ of global installed power capacity, and almost $99 \%$ of total storage capacity [16]. The rated power of individual pumped hydropower stations ranges from $1000 \mathrm{MW}$ to $5000 \mathrm{MW}$, with operating efficiencies of $75-85 \%$, lifetimes greater than 50 years. PHS provides good long-term stability to augment intermittent RE sources [8]. The main benefits of PHS are for energy management via time shift, supply reserve and non-spinning reserve [10], as well as long lasting lifetime and practically unlimited cycle stability; the key disadvantages are the large land use and the dependence on topographical conditions.

\section{3) Flywheels (FESS)}

FESS use conservation of angular momentum of a rotating mass, being charged and discharged using a motorgenerator to convert electricity to kinetic energy and vice versa. [19]. These systems exhibit high efficiencies of about $93 \%$ and lifetimes of 20 years, fast recharge and response and high energy density [20]; however, a drawback is the high level of self-discharge because of bearing losses and air resistance [10].

\section{B. Thermal Energy Storage}

Low temperatures storage systems can be separated into aquifer low temperature (AL-TES), which are not used in the electricity sector, and cryogenic (CES) energy storage, which uses off peak power or RE types to cool fluid to be utilised in a cryogenic heat engine to generate electricity. CES has not yet been proven and is still under development, but its capital cost is low and the energy density high. Nevertheless, efficiency of this type is currently low at (40-50\%) [8], [19].

High temperature thermal energy storage is in use and under development, including molten salt and sensible heat storage. Latent heat may used, in which energy is exchanged during a phase change. Alternatively, sensible heat may be stored. This is a common technology, with the domestic hot water reservoir as an example[10]. High temperature thermal energy storage has long cycle life ranging more than 13000 cycles and low environment impact whereas its efficiency is very low $(30-60 \%)[5],[24]$.

\section{Chemical Energy Storage:}

Chemical technologies can be categorised as conventional, advanced and flow batteries.

\section{1) Conventional batteries}

\section{i. $\quad$ Lead-acid battery (Pb-acid)}

There have been significant developments in lead-acid batteries since their invention by Gaston Planet in 1859 and they are generally inexpensive [5]. The cells of these batteries comprise a lead acid cathode and spongy lead anode, absorbed in a dilute sulphuric acid electrolyte, with lead as the current collector. Throughout discharge, on both electrodes, lead sulphate is generated [21]. Generally, this battery has a high efficiency $(80-90 \%)$ and reliability. The lead-acid battery is a good storage option for spinning reserve, energy management, and power quality applications, but suffer from a short cycle life (about 2000 cycles) and low energy density (30-50 Wh/kg) [8].

\section{ii. Nickel cadmium $(\mathrm{Ni}-\mathrm{Cd})$ and nickel metal hydride $(\mathrm{N}-\mathrm{MH})$ batteries}

$\mathrm{Ni}-\mathrm{Cd}$ batteries were the chemical choice between 1970 and 1990 for high-performance applications. Ni-Cd batteries have been prohibited for consumer use in the EU since 2006 [26] and are used only for stationary applications due to the toxicity of cadmium. More recently, lithium ion and nickel metal hydride have been preferred [21]. Although newer than lead-acid batteries, Ni-MH devices are considered mature and are better in terms of energy density, cycle life and maintenance requirements [19]. Nickel metal hydride batteries have 300-500 lifetime cycles, 70-75\% efficiency, fast response, and much higher energy densities [10]. 
2)

\section{Advanced batteries}

\section{i. $\quad$ Lithium ion (Li-ion) batteries}

Lithium ion batteries are widespread and commonly used in portable electronic devices, such as mobile phones and electric vehicles [21], [22], but can be expensive and prone to catastrophic failure, as recently highlighted by the high profile problems with Boeing 787 Dreamliners and the recall of Samsung Galaxy Note 7 devices. Key advantages are their energy-to-weight ratio, lack of memory effects and low selfdischarge. High levels of the cell voltage are up to 3.7 nominal Volts. These batteries have a very high efficiency (90-98\%) and standard cells with 4500 full cycles can be obtained [19], [10].

\section{ii. $\quad$ Sodium-sulphur batteries $(\mathrm{Na}-\mathrm{S})$}

The temperature of Na-S batteries is kept between $300^{\circ} \mathrm{C}$ and $350^{\circ} \mathrm{C}$ to keep the electrodes molten [10]. These batteries are considered to be a very attractive emerging technology, like wind power, because they can be cycled 2500 times and have long discharge cycles, fast response [11], high efficiency (85$90 \%$ ), and high power density $(150-240 \mathrm{~W} / \mathrm{kg})$ [4], [6]. A limitation is requiring a heat source to maintain operating temperature, which uses the battery's own stored energy, partly decreasing performance.

\section{iii. Sodium nickel chloride ( $\mathrm{NaNiCl}$ )}

$\mathrm{NaNiCl}$, or ZEBRA, batteries use nickel chloride as the anode. Like Na-S, they are a high temperature $\left(\sim 300^{\circ} \mathrm{C}\right)$ system, but can operate at temperatures of -40 to $70^{\circ} \mathrm{C}$ without cooling. ZEBRA batteries have a high cell voltage $(2.58 \mathrm{~V})$ and better safety characteristics than $\mathrm{Na}-\mathrm{S}$ batteries, able to withstand limited overcharge and discharge. They can be used in transport applications, but compared to Na-S batteries have lower power density (approximately $150 \mathrm{~W} / \mathrm{kg}$ ) and energy density (approximately $125 \mathrm{Wh} / \mathrm{kg}$ ) [5],[ 8].

\section{Fuel Cells (Hydrogen Energy Storage FC-HES)}

Electrochemical energy conversion devices come in many forms, including solid oxide (SOFC), phosphoric acid (PAFC), alkaline (AFC), molten carbonate (MCFC), and direct methanol (DMFC). These differ in terms of the electrolyte used, design, temperature range and target application. Additionally, there are specific fuel requirements for each type [15]. With high energy density, fast response and lifetimes exceeding 1000 cycles, fuel cells can be used for large and small scale applications [5], [22], [25], but they are presently expensive and have very low round trip efficiency (29-59\%) [19].

\section{E. Flow batteries}

A leading example of a flow, or redox, battery is that developed by Regenesys Technologies in 2002, with 15 $120 \mathrm{MWh}$ capacity using polysulfide bromide. More recently, electrochemical system relying on vanadium have been under development. The efficiency is approximately 75\% [15].
Flow batteries can be used for ramping, time shifting, frequency regulation and power quality [18]. Some of the key advantages are high power and energy capacity, nontoxic material usage, full discharge capability, and low-temperature operation. On the other hand, the main drawback of this technology is that moving mechanical parts are required [21]. Another example of flow battery is zink bromine $(\mathrm{ZnBr})$, the effeciency of this sytem is about $70-75 \%$ and acycle life of approximatly 2000 cycles. $\mathrm{ZnBr}$ has no memory effect .

\section{F. Electrical Energy Storage}

\section{1) Capacitors and supercapacitors (EDLC)}

Supercapacitors (electric double layer capacitors) can be charged considerably faster than chemical systems and their lifecycles are five orders of magnitude greater [1]. This type is best utilised for fast cycling applications because they have $84-95 \%$ cycle efficiency. In addition, these technologies are utilized for grid power quality and to regulate frequency. However, despite very long life, fast discharge, and being highly reversible [14], electrical capacitor systems are presently uncompetitive for energy applications where discharge times of minutes or more are needed due to the high cost of energy stored per unit and the low energy density [17].

\section{2) Superconducting magnetic energy storage systems} (SMES)

SMES can discharge rapidly producing high power output over short periods of time when the stored energy is needed [4]. Storage capacity increases with the size of the windings. The installed capacities of this technology are up to about $10 \mathrm{MW}$ and are mostly utilized for improving power quality [2].

The energy losses is zero because of The DC resistance of SMES is almost zero[19]. The efficiency of Superconducting magnetic for storing electricity is very high. Power is almost obtainable immediately, and output power is very high for a short time duration [11] however, this technology is expensive [19].

\section{COMPARISON OF DIFFERENT ENERGY STORAGE}

The key characteristics of the ESS and their importance within different applications are offered here.

\section{A. Cycle efficiency: Three classes can be identified:}

1) Very high efficiency (>90\%): lithium ion batteries, flywheels, super capacity and superconducting magnetic.

2) High efficiency (60-90\%): pumped-hydro, non-lithium batteries, conventional capacitors and flow batteries.

3) Low efficiency (<60\%): hydrogen, high temperature thermal and compressed air energy storage.

\section{B. Lifetime and cycle life:}

years or cycles can be used to measure the lifetime of an ESS technology. lifetimes of both pumped-hydro and compressed air storage are the longest (50-100 and 25-40 years, respectively). Flywheel technology also has a very 
long cycle life $(\sim 100,000$ cycles $)$ whereas $\mathrm{Pb}-$ acid, $\mathrm{NiMH}$ and $\mathrm{ZnBr}$ have much more limited lifetimes.

\section{Environmental impact:}

The environmental impact of pumped-hydro and compressed air are the highest. Some technologies contain toxic materials and cause potential risks, e.g. lead, bromine and cadmium in batteries. Flywheels generally have very low environmental impact during normal operation.

\section{Discharge time: Three classes can again be identified:}

1) Short discharge time: (from seconds to minutes): flywheels, double-layer capacitors and superconducting magnetic energy storage.

2) Medium discharge time (from minutes to hours): All chemical energy types, e.g. Li-ion and $\mathrm{Pb}$-acid batteries.

3) Long discharge time (days to months): pumped hydro, compressed air and redox flow batteries, hydrogen and high temperature thermal.

\section{E. Technical maturity:}

ESS technical maturity is illustrated in Figure 1.

1) Mature technologies: Pb-acid battery and pumpedhydro storage have been used for more than a century .

2) Developed technologies: developed and commercially obtainable types include capacitors, superconducting magnetic, super capacitors, HT-TES ,CAES, NiCd, NaS, Liion, flow batteries, and flywheels; but are still not commonly used in large applications.

3) Developing technologies: fuel cells are still under active research and development, but not yet commercially mature.

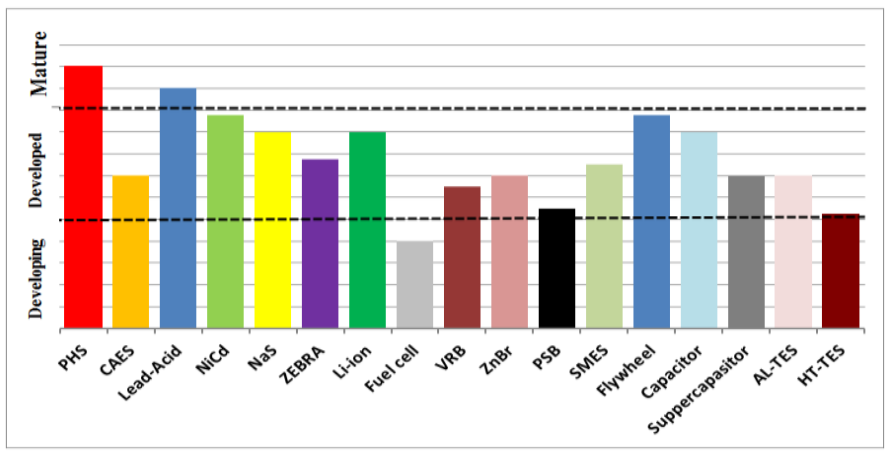

Figure 1: Technical maturity of ESS [9, 25]

\section{F. Storage duration:}

Self-discharge (energy dissipation) per day for ESS is shown in Table 1. It can be seen that PHS, CAES, fuel cells and flow batteries are suitable for long storage periods due to low selfdischarge ratios. $\mathrm{Pb}$-acid, $\mathrm{NiCd}$ and $\mathrm{Li}$-ion batteries exhibit intermediate self-discharge ratios, whereas $\mathrm{NaS}$, superconducting magnetic, capacitor and super capacitors very high ratios (10-40\% per day). Flywheels will discharge up to $100 \%$ in a day.
VI. DISCUSSION OF ENERGY STORAGE APPLICATIONS Energy storage applications for power systems can be combined at different levels: generation, transmission, distribution, and customer level. Some examples cases of ESS application are summarized in Table 2. These highlight several benefits of ESS related to distribution networks.

\section{A. Distribution Upgrade Deferral}

Distribution upgrade deferral includes utilizing storage in order to reduce the need for investments which would otherwise be essential to keep suitable distribution capacity to service load demands [8], [13].

\section{B. Customer Energy Management Services:}

1) Power quality: the service of power in the electrical sector includes ES to maintain supply for downstream consumers during brief interruptions or issues with power quality. ESS technologies that can deal with power quality related issues require high cyclability and fast response rates [8], [13].

2) Power reliability: ESS can efficiently support customer loads in the event of total power total loss. During a grid outage, the energy storage and customer loads island and resynchronize with the main grid when the supply is resumed. The capacity of ESS relative to the load size it is protecting find the period that the ES can supply power to the load. This duration can be prolonged by combining use of the ESS with a diesel generator that can support the customer through long outages that are beyond the ESS alone [8],[13].

Both PHS and CAES are presently appropriate only for large power and high storage applications, because the capital cost is high, environmental harm may be caused (e.g, flooding 10$20 \mathrm{~km}^{2}$ of land to build reservoirs), and long project lead times (typically 10 years) [1]. ESS is considered to be a vital technology for distributed energy resources. In contrast to the conventional grid, which has large centralized units, distributed installations close to where the power is used are typical, to produce power from $\mathrm{kW}$ to a few MW. On islanded networks and micro-grids, the advantages of ESS become even more relevant.

From Table 2 it is clear that ESS like HES, BES, FBES, FESS, SCES and SMES have been used to benefit distribution networks. According to Table 1, high efficiency provided by $\mathrm{Li}$-ion, $\mathrm{NaNiCl}, \mathrm{Pb}$-acid, FESS, SCES and SMES at present, with Li-ion slightly better, whereas hydrogen has low efficiency (29-49) \%. Li-ion batteries also have a considerably higher energy density $\left(620 \mathrm{kWh} / \mathrm{m}^{3}\right)$. Self-discharge rates for FESS and EDLCs are very high (100\% and $20-40 \%$ per day respectively), whereas the rates for $\mathrm{Pb}-$ acid and $\mathrm{Li}$-ion are very low $(0.1-0.3 \%$ per day). $\mathrm{SMES}, \mathrm{NaNiCl}$ and $\mathrm{NaS}$ are in the middle with self-discharge rates of $10-20 \%$ per day. Li-ion, $\mathrm{NaS}$ and V-redox batteries can get more cycles than rechargeable batteries like leadacid, $\mathrm{NiMH}$ and $\mathrm{ZnBr}$ with a comparatively limited lifetime of less than 3000 cycles. 
$\mathrm{Pb}$-acid batteries are a very mature technology, SMES, and flywheel, NaS, NiCd, Li-ion, flow batteries, double layer capacitor are developed technology. Memory effect is another feature featuring in Table 1, related primarily to batteries and described as "a reduced discharge capacity when the battery is incompletely discharged and recharged" [2].

This characteristic is a drawback of $\mathrm{NiCd}$ and $\mathrm{NiMH}$ systems. Capital cost is the key issue for the industrial takeup of the EES. Pb-acid batteries have low capital cost while $\mathrm{Li}$-ion batteries are still expensive.

\section{SUMMARY}

An overall review of the main features of ESS and their importance within several applications in the environmental built has been outlined in this report. Both PHS and CAES are presently appropriate for large-scale power and highenergy storage uses such as bulk energy, ancillary and transmission infrastructure services.

For distribution networks, HES, BES, FBES, FESS, SCES and SMES are technically viable. Li-ion batteries look very capable devices for advanced ESS incorporation in the built environment with energy density of $620 \mathrm{kWh} / \mathrm{m}^{3}$. However, because Li-ion batteries are still expensive, the lead-acid battery continues to be the best compromise between both cost and performance.

\section{REFERENCES}

[1] M. Beaudin, H. Zareipour, A. Schellenberglabe, and R. William. "Energy storage for mitigating the variability of renewable electricity sources: An updated review." Energy for Sustainable Development 14, no. 4 (2010): 302-314.

[2] A. Chatzivasileiadi, A. Eleni, and K. Ian. "Characteristics of electrical energy storage technologies and theirapplications in buildings." Renewable and Sustainable Energy Reviews 25 (2013): 814-830.

[3] A. Srivastava, A. Kumar, and A. Schulz. "Impact of distributed generations with energy storage devices on the electric grid." Systems Journal, IEEE 6, no. 1 (2012): 110-117.

[4] The APS Panel on Public Affairs Committee on Energy and Environment, "Challenges of Electricity Storage Technologies," 2007.

[5] X. Tan, L. Qingmin, and W. Hui. "Advances and trends of energy storage technology in Microgrid." International Journal of Electrical Power \& Energy Systems 44, no. 1 (2013): 179-191.

[6] A. S. A. Awad, M. M. A. Salama and T. H. M. EL-Fouly "Energy Storage for Microgrids Islanding Operation." In 3rd International Conference on Electric Power and Energy Conversion Systems Conference Proceedings, Turkey. 2013 A. S.

[7] K. Chatzivasileiadi. "Electrical energy storage technologies and the built environment." In International Renewable Energy Storage Conference.

[8] H. Chen, NC. Thang, Y. Wei, T. Chunqing, L. Yongliang, and D.Yulong. "Progress in electrical energy storage system: A critical review." Progress in Natural Science 19, no. 3 (2009): 291-312.

[9] A. Mohd, O. Egon, S. Andreas, H. Nedzad, and M. Danny. "Challenges in integrating distributed energy storage systems into future smart grid." In Industrial Electronics, 2008. ISIE 2008. IEEE International Symposium on, pp. 1627-1632. IEEE, 2008.

[10] Electrical Energy Storage project team, International Electrotechnical Commission. "Electrical energy storage" white paper IEC WP EES:2011-12(en).

[11] J. Makansi, and J. Abboud. Energy Storage. Energy Storage Council "energy storage," An ESC White Paper, 2002.
[12] DOE, US. "Grid 2030: A national vision for electricity's second 100 years." US DOE Report 2003.

[13] A. Akhil., G. Huff, A. Currier, B. Kaun, D. Rastler, S. Chen, A. Cotter, D. Bradshaw, and W. Gauntlett. "Electricity Storage Handbook in Collaboration with NRE CA."SANDIA REPORT SAND2013-5131 Unlimited Release July 2013.

[14] P. Medina, A. W. Bizuayehu, João PS Catalão, E. M. G. Rodrigues, and J. Contreras. "Electrical Energy Storage Systems: Technologies' Stateof-the-Art, Techno-economic Benefits and Applications Analysis." In System Sciences (HICSS), 2014 47th Hawaii International Conference on, pp. 2295-2304. IEEE, 2014.

[15] H. Ibrahim, I. Adrian, and P. Jean. "Energy storage systemscharacteristics and comparisons." Renewable and sustainable energy reviews12, no. 5 (2008): 1221-1250.

[16] Barbour E, Wilson IG, Radcliffe J, Ding Y, Li Y. A review of pumped hydro energy storage development in significant international electricity markets. Renewable and Sustainable Energy Reviews. 2016 Aug 31;61:421-32.

[17] European Association for Storage of Energy, (2013). Joint EASE/EERA recommendations for a European Energy Storage Technology Development Roadmap towards 2030 [Online]. Available web

site: https://www.energinet.dk/SiteCollectionDocuments/Danske\%20dokum enter/Forskning\%20-\%20PSOprojekter/Allan\%20Schr\%C3\%B8der\%20Pedersen $\% 20$ $\% 20$ EASE\%20EERA\%20anbefalinger.pdf

[18] U.S. Department of Energy. (2013). Grid Energy Storage. [Online] Available web site: http://energy.gov/sites/prod/files/2013/12/f5/Grid\%20Energy\%20Stora ge\%20December\%202013.pdf

[19] A. Evans, V. Strezov, and T.J. Evans. "Assessment of utility energy storage options for increased renewable energy penetration." Renewable and Sustainable Energy Reviews 16, no. 6 (2012): 4141-4147.

[20] Ren G, Ma G, Cong N. Review of electrical energy storage system for vehicular applications. Renewable and Sustainable Energy Reviews. 2015 Jan 31;41:225-36.

[21] S. Vazquez , S. M. Lukic , E. Galvan , L. G. Franquelo and J. M. Carrasco, "Energy storage systems for transport and grid applications", IEEE Trans. Ind. Electron., vol. 57, no. 12, pp. 3881-3895, 2010

[22] N. Meena, V. Baharawani, A. Dubey, U. Brighu and J. Mathur, 2014. Need and Comparison of Energy Storage Technologies--A Review. Int. J. Appl. Eng. Res, 9, pp.177-184.

[23] P. Trichakis, P. C. Taylor, L. M. Cipcigan, P. F. Lyons, R. Hair, and T. Ma. "An investigation of voltage unbalance in low voltage distribution networks with high levels of SSEG." In Proc. 41st International Universities Power Engineering Conference, vol. 1, pp. 182-186. IEEE, 2006.

[24] W. Friedl, L. Fickert, E. Schmautzer, and C. Obkircher. "Safety and reliability for smart-, micro-and islanded grids." In Smart Grids for Distribution, 2008. IET-CIRED. CIRED Seminar, pp. 1-4. IET, 2008

[25] H. Zhao, Q. Wu, S. Hu, H. Xu, and CN. Rasmussen. "Review of energy storage system for wind power integration support." Applied Energy 137 (2015): 545-533.

[26] Directive, Battery. "Directive 2006/66/EC of the European Parliament and of the Council of 6 September 2006 on batteries and accumulators and waste batteries and accumulators and repealing Directive 91/157/EEC." OJ L 266, no. 26.9 (2006): 2006.

[27] J. Alba. Rios, P. Birkner, F. Hakan, A. Kroll, P. Lawson and P. Lebreton. "Decentralised storage: impact on future distribution grids." Brussels, Belgium: Union of the Electricity Industry 2012. 
Table 1: Comparison among candidate storage technologies

\begin{tabular}{|c|c|c|c|c|c|c|c|c|c|c|c|c|c|c|c|}
\hline & Phs & CAES & Hydrogen & Flywheel & SMES & EDLC & $\mathrm{Pb}$ acid & $\mathrm{NiCd}$ & NiMH & Li-ion & $\mathrm{NaS}$ & $\mathrm{NaNiCl}$ & V redox & $\mathrm{ZnBr}$ & $\begin{array}{c}\text { Thermal } \\
\text { (HT-TES) }\end{array}$ \\
\hline Efficiency \% & $75-85$ & $\leq 55$ & $29-49$ & $85-95$ & $\geq 95$ & $84-95$ & $80-90$ & 90 & $70-75$ & 90-98 & $85-90$ & 90 & 75 & $70-75$ & $30-60$ \\
\hline $\begin{array}{c}\text { Power rating } \\
\text { MW }\end{array}$ & $100-5000$ & $100-300$ & $<50$ & 20 & $0.01-10$ & $0.01-1$ & $<70$ & $<40$ & $\begin{array}{l}10 \gamma(-6) \\
-0.2 \\
\end{array}$ & $0.1-5$ & $0.5-50$ & $<1$ & $0.37-7$ & $0.5-2$ & 0.60 \\
\hline $\begin{array}{l}\text { Energy density } \\
\mathrm{kWh} / \mathrm{m}^{3}\end{array}$ & $0.2-2$ & 12 & 600 & $20-80$ & 6 & $10-20$ & $\sim 75$ & $<200$ & $<50$ & $250-620$ & $<400$ & $150-200$ & $20-35$ & - & \\
\hline $\begin{array}{c}\text { Power density } \\
\mathrm{kW} / \mathrm{m} 3\end{array}$ & $0.1-0.2$ & $0.2-0.6$ & $0.2-20$ & 5000 & 2600 & $\begin{array}{l}40000- \\
120000 \\
\end{array}$ & $90-700$ & $75-700$ & $500-3000$ & $\begin{array}{l}1300- \\
10000\end{array}$ & $120-160$ & $250-270$ & $0.5-2$ & $1-25$ & - \\
\hline $\begin{array}{l}\text { Specific energy } \\
\text { Wh/kg }\end{array}$ & $0.5-1.5$ & $30-60$ & 33,330 & $5-130$ & 0.5 .5 & $0.1-15$ & $30-50$ & $45-80$ & $60-120$ & $100-250$ & $100-250$ & 125 & 75 & $60-80$ & - \\
\hline Lifetime (Cycle) & $>13000$ & $>13000$ & $>1000$ & $>100000$ & $>100000$ & $>100000$ & 2000 & 3000 & $300-500$ & 4500 & 4500 & $\begin{array}{l}1000- \\
2500\end{array}$ & 12000 & 2000 & $>13000$ \\
\hline Lifetime (years) & $50-100$ & $25-40$ & $5-15$ & $\geq 20$ & $\geq 20$ & $\geq 20$ & $3-15$ & $15-20$ & $5-10$ & $8-15$ & $12-20$ & $12-20$ & $10-20$ & $5-10$ & $5-15$ \\
\hline $\begin{array}{l}\text { Suitable Storage } \\
\text { Duration }\end{array}$ & h-months & h-months & h-months & $s-\min$ & $\min -h$ & s-h & min-days & min-days & - & min-days & s-h & s-h & h-months & h-months & $\begin{array}{c}\text { min- } \\
\text { months }\end{array}$ \\
\hline $\begin{array}{l}\text { Self-discharge } \\
\text { per day } \%\end{array}$ & 0 & 0 & $0.5-2$ & $20-100$ & $10-15$ & $2-40$ & $0.1-0.3$ & $0.2-0.6$ & $0.4-1.2$ & $0.1-3$ & 20 & 15 & $0-10$ & 0.1 & $0.015-1$ \\
\hline recharge time & $\min -h$ & $\min -h$ & instantaneous & $<15$ min & $\min$ & s to $\min$ & $8-16 \mathrm{~h}$ & $1 \mathrm{~h}$ & $2-4 \mathrm{~h}$ & $\min -\mathrm{h}$ & $\sim 9 \mathrm{~h}$ & $6-8 \mathrm{~h}$ & $\min$ & $3-4 \mathrm{~h}$ & - \\
\hline Response Time & $s-\min$ & $1-15 \mathrm{~min}$ & $\mathrm{~ms}-\min$ & ms-s & $\mathrm{ms}$ & $\mathrm{ms}$ & $\mathrm{ms}$ & $\mathrm{ms}$ & $\mathrm{ms}$ & ms-s & $\mathrm{ms}$ & $\mathrm{ms}$ & $<1 \mathrm{~ms}$ & $<1 \mathrm{~ms}$ & - \\
\hline $\begin{array}{c}\text { Environmental } \\
\text { impact }\end{array}$ & 1 & 1 & 3 & 5 & 3 & 3 & 2 & 4 & 3 & 4 & 4 & - & 3 & 3 & 3 \\
\hline $\begin{array}{c}\text { Inv. Power cost } \\
\qquad / \mathrm{Kw}\end{array}$ & $500-3600$ & $400-1150$ & $550-1600$ & $100-300$ & $100-400$ & $100-400$ & $200-650$ & $350-1000$ & $\begin{array}{c}120 \% \times \\
\mathrm{NiCd}\end{array}$ & $700-3000$ & $700-2000$ & $100-200$ & 2500 & $500-1800$ & - \\
\hline $\begin{array}{c}\text { Inv. energy cost } \\
\qquad / \mathrm{kWh}\end{array}$ & $60-150$ & $10-40$ & $1-15$ & $1000-3500$ & $700-7000$ & $\begin{array}{l}300- \\
4000 \\
\end{array}$ & $50-300$ & $200-1000$ & $\begin{array}{c}120 \% \times \\
\text { NiCd }\end{array}$ & $200-1800$ & $200-900$ & $70-150$ & $100-1000$ & $100-700$ & - \\
\hline Maintenance & 3 & 3 & 1 & 3 & 2 & 4 & 3 & 1 & 1 & 5 & 3 & 5 & 3 & 1 & - \\
\hline Memory effect & $\mathrm{N} / \mathrm{A}$ & $\mathrm{N} / \mathrm{A}$ & N/A & No & $\mathrm{N} / \mathrm{A}$ & No & No & Yes & Yes & No & No & No & No & No & - \\
\hline REFERENC & $2,5,8,19$ & $2,5,8,19$ & $2,5,8,19$ & $2,5,8,19$ & $2,5,8,19$ & $2,5,8,19$ & $2,5,8,19$ & $2,5,8,19$ & $2,5,19$ & $2,5,19$ & $2,5,8,19$ & $2,5,8,19$ & $1,2,5,8,19$ & $1,2,5,8,19$ & 5,19 \\
\hline
\end{tabular}

- N/A- Not available in the literature, Not app 1: Not applicable

- For maintenance and impact of environment: $1=$ High, $2=$ Medium, $3=$ Low, $4=$ very low and 5=No

- Time: $\mathrm{s}=$ second, $\min =$ minute, $\mathrm{h}=$ hour $\& \mathrm{~ms}=$ millisecond

Table 2: Energy storage system Application [14]

\begin{tabular}{|c|c|c|c|c|c|c|c|c|c|c|c|c|c|c|}
\hline \multirow{2}{*}{\multicolumn{3}{|c|}{$\begin{array}{c}\underset{\times}{\text { ES Technologies }} \rightarrow \\
\text { Applications } \\
\downarrow \\
\downarrow\end{array}$}} & \multicolumn{3}{|c|}{ Applications requirements } & \multirow{3}{*}{$\begin{array}{l}1 \\
\qquad \frac{a}{2} \\
*\end{array}$} & \multirow{3}{*}{$\begin{array}{l}2 \\
\\
0 \\
0 \\
0 \\
0\end{array}$} & \multirow{3}{*}{ 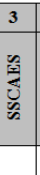 } & \multirow{3}{*}{ 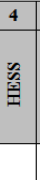 } & \multirow{3}{*}{5} & \multirow{3}{*}{6} & \multirow{3}{*}{ 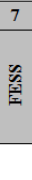 } & \multirow{3}{*}{8} & \multirow{2}{*}{9} \\
\hline & & & 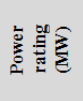 & 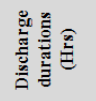 & 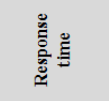 & & & & & & & & & \\
\hline \multirow{2}{*}{$\begin{array}{l}\text { Electric } \\
\text { supply }\end{array}$} & Utility system & Provide system capacity /electric supply capacity /base load investment deferral & $1-1000$ & 4-6 & Mins & & & & & & & & & \\
\hline & \multirow{5}{*}{$\begin{array}{c}\text { Independent } \\
\text { system } \\
\text { operator }\end{array}$} & $\begin{array}{c}\text { Energy price Arbitrage /Time -shift /RE time shift/load leveling and peak } \\
\text { shaving }\end{array}$ & 10-1000 & $2-10$ & Mins & $*$ & $*$ & & $*$ & $*$ & $*$ & & & \\
\hline \multirow{4}{*}{$\begin{array}{l}\text { Ancillary } \\
\text { services }\end{array}$} & & $\begin{array}{l}\text { Load following /provide spin \&non spin reserves/Electric supply reserve capacity } \\
\text { /conventional spinning reserve/Terciary Regulation }\end{array}$ & 10-1000 & $2-4$ & Mins & $*$ & $*$ & $*$ & $*$ & $*$ & $*$ & & & \\
\hline & & Fast response spinning reserve /secondary regulation & $10-1000$ & $1-2$ & $<30$ Secs & $*$ & $*$ & $*$ & $*$ & $*$ & $*$ & & & \\
\hline & & Provide voltage \&frequency regulation/Area regulation/Primary Regulation & $1-1000$ & $\begin{array}{l}15-30 \\
\text { Mins }\end{array}$ & Immediate & & & & $*$ & $*$ & $*$ & $*$ & & * \\
\hline & & Provide Black-start and Ramp/Power system start up & $\begin{array}{l}100- \\
1000\end{array}$ & $1-6$ & Secs & $*$ & $*$ & & $*$ & $*$ & $*$ & & & \\
\hline \multirow{3}{*}{$\begin{array}{l}\text { Renewables } \\
\text { integration }\end{array}$} & \multirow{3}{*}{ Utility system } & $\begin{array}{l}\text { RE integration(seasonally output shifting/Renewable capacity firming/renewable } \\
\text { Back-up }\end{array}$ & $\begin{array}{c}0.0001- \\
400\end{array}$ & $2-4$ & Mins & $*$ & $*$ & $*$ & $*$ & $*$ & $*$ & & & \\
\hline & & $\begin{array}{l}\text { RE integration (daily output shifting)/Renewable generation grid integration } \\
\text { /load leveling. }\end{array}$ & $0.2-400$ & $1-6$ & Mins & $*$ & $*$ & $*$ & $*$ & $*$ & $*$ & & & \\
\hline & & $\begin{array}{l}\text { Centralized RE integration (smoothing)/renewables generation grid integration } \\
\text { (short duration)/fluctuation suppression. }\end{array}$ & $0.2-400$ & $\begin{array}{l}\text { 10Secs- } \\
15 \text { Secs }\end{array}$ & Secs -Mins & & $*$ & $*$ & $*$ & $*$ & $*$ & $*$ & $*$ & $*$ \\
\hline \multirow{4}{*}{ Grid system } & transmission & $\begin{array}{c}\text { Transmission congestion relief /Defer Transmission investment /transmission } \\
\text { Upgrade Deferral }\end{array}$ & $\begin{array}{l}0.25- \\
100\end{array}$ & $2-6$ & Mins & $*$ & $*$ & $*$ & $*$ & $*$ & $*$ & & & \\
\hline & \multirow{3}{*}{ Distribution } & Reduce Outage Frequency -Duration /Electric Service Reliability /UPS & $\begin{array}{c}0.002- \\
10\end{array}$ & 4-10 & Sec-Mins & & & $*$ & $*$ & $*$ & $*$ & $*$ & & \\
\hline & & Defer Distribution Investment /Distribution Upgrade Deferral & $0.25-10$ & 2-6 & Mins & & & $*$ & $*$ & $*$ & $*$ & & & \\
\hline & & $\begin{array}{l}\text { Provide voltage support grid stabilization /transmission support/voltage control } \\
\text { support }\end{array}$ & $10-100$ & $>15$ Mins & $<1 / 4$ Cycle & * & & * & * & $*$ & * & $*$ & * & * \\
\hline \multirow[b]{2}{*}{ Customer } & \multirow[b]{2}{*}{ End-user } & Improve power reliability/Electric service reliability /UPS & $\begin{array}{c}0.002- \\
10\end{array}$ & 5Mins-2 & $<1 / 4$ Cycle & & & & * & * & * & $*$ & * & \\
\hline & & $\begin{array}{l}\text { Improve power quality /electric service power quality /transit and end use ride } \\
\text { through oscillation damping }\end{array}$ & $\begin{array}{c}0.002- \\
10\end{array}$ & $\begin{array}{l}\text { 10sec- } \\
15 \text { Mins }\end{array}$ & $<\mathbf{1} / \mathbf{4}$ Cycle & & & & * & * & * & * & * & * \\
\hline
\end{tabular}

